\title{
Value logics for service innovation: practice-driven implications for service-dominant logic
}

\author{
Erik Lindhult ${ }^{1}$ - Koteshwar Chirumalla ${ }^{1}$ - Pejvak Oghazi ${ }^{2,5}$ • \\ Vinit Parida ${ }^{3,4}$
}

\begin{abstract}
Service-dominant logic (SDL) provides a conceptual understanding of and widens the view on value creation in service innovation for product-centric companies. However, empirical research linking SDL and service innovation is still limited albeit expanding. This study provides insights beyond existing discussions on product and service dimensions using the theoretical lens of the value logic perspective. More specifically, the purpose of this study is to examine how value can be understood, targeted, and created in the pursuit of service innovation by product-centric manufacturing companies. Building on a previous investigation of two multinational product-centric manufacturing companies, this paper identifies and develops a theoretical model to describe the space shift in service innovation with four different kinds of value logics, namely, product-based value logic, servicebased value logic, virtual-based value logic, and systemic-based value logic. Using
\end{abstract}

Pejvak Oghazi

pejvak.oghazi@sh.se

Erik Lindhult

erik.lindhult@mdh.se

Koteshwar Chirumalla

koteshwar.chirumalla@mdh.se

Vinit Parida

vinit.parida@1tu.se

1 School of Innovation, Design and Engineering, Mälardalen University, Box 325, 63105 Eskilstuna, Sweden

2 Business Studies, School of Social Sciences, Södertörn University, 14189 Huddinge, Sweden

3 Department of Business Administration, Technology and Social Sciences, Luleå University of Technology, 97187 Luleå, Sweden

4 Department of Management, University of Vaasa, P.O.Box 700, Vaasa, Finland

5 School of Business and Economics, Linnaeus University, Vaxjo, Sweden 
a digitalization-driven new service innovation, namely the My Control System, which is a web-based service delivery platform, this paper describes space shifts to enhance value through four value logics as efforts. Further, challenges associated with different value logics are described in terms of complexity traps and service gaps. The study also contributes to bridging the gap between SDL theory and practice by developing a midrange theoretical model for value creation as a specification and amendment to SDL that supports SDL-guided service innovation and servitization in practice.

Keywords Servitization · Product-service system · Advance services · Value co-creation · Digitalization $\cdot$ Business model innovation

\section{Introduction}

Servitization is often used as an opportunity to increase service business potential and revenue potential in product-centric manufacturing companies faced with stronger competition and commoditization in traditional product business (Vandermerwe and Rada 1988; Ostrom et al. 2015; Kowalkowski et al. 2017). The degree of servitization in manufacturing companies has increased over the years in most countries (e.g., Neely et al. 2011) and has been extensively researched as a development method for service business (Gebauer et al. 2008; Fischer et al. 2012), as a service transition (Fundin et al. 2012; Parida et al. 2014). Regardless of diverging views, at their core, servitization processes represent a transformative challenge that include many dimensions. An important dimension in the servitization journey is enhancing ability and enabling space for service innovation (e.g., Gebauer et al. 2008; Paswan et al. 2009). As is largely prevalent in the literature, the product-centric method of service innovation is still perceived and pursued in many industrial companies. For example, some companies add value to products by adding services, while others use a "service infusion" (Eloranta and Turunen 2015). Although this is helpful when taking progressive steps on a servitization journey, this approach is not able to realize a fuller potential of service innovation. Hence, there is a need for liberation from product-centric thinking and practices in service innovation to widen the space for more service-conducive innovation framing and activity in the context of predominantly product-centric companies.

Researchers have used value creation to understand the emerging spaces that are required for service innovation (e.g., Lindgreen et al. 2012; Fischer et al. 2012; Grönroos 2012). In using the notion of "value" and "value-in-use", a seminal work on service-dominant logic (SDL) provided a theoretical understanding of how companies and customers create value together (Vargo and Lusch 2004; Lusch and Vargo 2014). SDL is a perspective and meta-idea on service and value creation framing business and markets in terms of two logics of value creation: goodsdominant (G-D) logic with a focus on value in exchange and service dominant (S-D) logic with a focus on value in use (Vargo and Lusch 2004; Lusch and Vargo 2014) embedded in products. It was initially conceived not as a theory but as a counter paradigmatic challenge to the prevalent G-D logic in marketing (Vargo and Lusch 
2008). SDL points to and inspires a movement towards S-D logic in seeing value that is understood as emerging in the context of use. Over the last decade, it has been expanding in service research and marketing, and has also begun to influence areas such as industrial operation and innovation, along with the understanding of service in servitization efforts in industrial companies (Grönroos and Helle 2010; Mele et al. 2014; Pohlmann and Kaartemo 2017; Smith et al. 2014). SDL widens and transforms the view on value creation in servitization and service innovation in product-centric contexts from product use to customer processes and further to value co-creating processes and service (eco-) systems (Vargo et al. 2015). An SDL view generally leads towards synthesis and integration between the innovation of products, technologies, and services into an understanding of service innovation as an enabling and enhancing collaborative process of value co-creation (Witell et al. 2016).

However, research linking SDL and service innovation is still limited albeit expanding (Michel et al. 2008a; Ordanini and Parasuraman 2011; Edvardsson and Tronvall 2013; O’Cass et al. 2013; Korhonen 2014; Skålén et al. 2014; Lusch and Nambisan 2015; Pohlmann and Kaartemo 2017). A core issue for service innovation from an SDL perspective is how it can conceptualize, envision, and pursue innovation of enhanced and new value in practice. SDL opens up new ways of thinking on value, value creation, and pursuing service innovation, which, according to main proponents, are revealing unlimited and unbounded opportunities for value creation and market expansion (Lusch and Vargo 2014, p. 204). But the link between SDL as a paradigm and perspective to specific industrial service innovation practices has only been empirically researched to a limited extent, and is conceptually unclear (Ballantyne et al. 2013). The most fruitful and practically useful way to understand service innovation from an SDL view is still an open issue. Gustafsson et al. (2016) specified a typology of service innovation (process, brand, experience, social, business model, and behavior innovations) based on different ways to facilitate the value creation of customers. Paswan et al. (2009) developed a quite different typology based on three context dimensions: environmental uncertainty, strategic orientation, and market orientation. Both studies proposed typologies to enrich the innovation potential to support managers who are responsible for service innovation.

Nevertheless, studies providing deeper insights beyond discussion into product and service dimensions are limited, especially from the theoretical lens of the value logic perspective (e.g., Paswan et al. 2009). SDL's use as a guiding framework to understand the value logics of different sites and spaces for service innovation has not been explored. In particular, the empirically rooted extension of SDL has not been undertaken. To address this research gap, this study attempts to take advantage of SDL as a conceptual resource for framing how to understand service innovation, which is helpful in the effort to widen space and opportunities for servitization. The purpose of this study is, therefore, to examine how value can be understood, targeted, and created in service innovation pursued within different spaces by manufacturing companies.

To achieve the stated purpose, an empirical study was carried out in two phases within two multinational manufacturing companies focusing on service innovation 
conditions and servitization. The first phase was focused on understanding the characteristics and conditions for servitization in general for both companies, and the second phase was mainly focused on one of the company's flagship digitalization-driven new service innovation initiatives, called the My Control System (MCS), which is a new web-based service delivery platform. The paper identifies and categorises the MCS's space shift in service innovation using four different kinds of value logics, namely, product-based, service-based, virtual-based, and systemic-based value logic. Based on this categorisation, a theoretical model of value logic for service innovation is presented and validated using the MCS case.

The present study holds numerous theoretical and practical implications for servitization (e.g., Baines et al. 2009; Cenamora et al. 2017; Vandermerwe and Rada 1988) and enabling service innovation (e.g., Ostrom et al. 2015; Lusch and Nambisan 2015; Toivonen 2016; Witell et al. 2016). Specifically, the study aims to bridge the gap between SDL (e.g., Ballantyne et al. 2013; Edvardsson and Tronvall 2013; Korhonen 2014; Ordanini and Parasuraman 2011), its practical deployment, and its development into a theory of value creation (e.g., Fischer et al. 2012; Grönroos and Helle 2010; Lindgreen et al. 2012; Skålén et al. 2014) by developing a midrange theoretical model (e.g., Brodie et al. 2011) that can support SDL-guided service innovation and servitization in practice.

The remainder of the paper is organised as follows. Section 2 introduces the theoretical background and summarises it using a theoretical model of different value logics, and the following section describes the research method. Section 4 presents the story of the MCS and its application in different value logics. Section 5 discusses the potential opportunities and challenges with different value logics in relation to the existing theory. The key conclusions and plans for future research are discussed in the final section.

\section{Value logics for service innovation: a theoretical model}

In this section, a theoretical model outlining value logics for service innovation is developed as a specification and amendment of SDL. The section initially covers a brief introduction to value and SDL, describes four different value logics, and finally presents the theoretical model.

\subsection{Value and SDL}

Value has received increasing attention, with the SDL stream of research becoming an important inspiration (Vargo and Lusch 2012). In business research and practice, the focus on customer value, particularly in the subfields of marketing and service research, has been quite self-evident for a long time (Holbrook 1994; Anderson and Narus 1998). However, a recent overview by leading researchers stated that "the creation of value is paramount to any company's survival ... and yet academics and practitioners alike agree that we have only just begun to understand what 'value' means" (Lindgreen et al. 2012, p. 207). SDL, with its focus on value-in-use based on 
a long historical tradition (Vargo and Lusch 2004), provides fruitful suggestions in its core focus on value, co-creation, and service (Grönroos 2012).

Value is important for actors and is expressed through purposeful action (von Mises 1949) and consummatory experience of use and enjoyment (Dewey 1939; Menger 2007; $\mathrm{Ng}$ and Smith 2012). As the theory of valuation of pragmatic philosopher John Dewey $(1939,2008)$ pointed out, in line with SDL, value is included not only as the ends, but also in the activity and requisite affordances within its generation, implying a close interconnection between service and value creation. Service means the deeds, processes, and performances enacted by one party for the benefit of another party, that is, action or work by actors supporting value creation for other actors (Vargo and Lusch 2004; Lusch and Vargo 2014). Servicing, therefore, means the application of specialized knowledge and skills and other resources (e.g., tools, equipment, information systems; social and symbolic resources such as relations, trust, and brands) to enable the requisite value-creating activities.

Value in situated use and enjoyment is also contextual both as ends and in its generation and innovation (Dewey 2008; Chandler and Vargo 2011; Paswan et al. 2009). Experience is doing and undergoing the consequences in particular situations, according to Dewey (1939), confirming the active, co-creative role of users as SDL points (Prahalad and Ramaswamy 2004). For example, the value in servicing spare parts in recovering the functionality of products and services is often, to a high degree, conditional on when and where the loss of functionality occurred. If my car suddenly stops while driving, a service need occurs at that particular moment and situation. I can then activate a value-creating activity for recovery of my transportation functionality (e.g., calling friends to tow the car to a repair shop and then lending another car), which, if I have such service included in my car insurance, then the insurance company can enable the activation of a preorganized service system.

Generally, servicing requires action and work and the application and integration of resources by a number of actors in collaboration. SDL has recently pointed to a shift towards a systemic understanding of innovation and an actor-centric point of departure for understanding both service and value (Gummesson 2008; Vargo and Lusch 2011). In a broader systemic perspective, servicing, according to SDL, is reciprocal and synergistic wherein the involved parties are servicing each other or helping each other in forming value co-creating systems (Normann 2001) or service (eco-) systems (Vargo et al. 2015) as part of a service economy in general. It is a barter economy, service exchange for service, in a novel perspective (Vargo and Lusch 2011). In this broadened view on value and value creation, value in use cannot be focused only on customers, but it must also recognize the need for value co-creation, and thus value in situated use, for all involved actors as a condition for their willingness to serve in the system.

Service innovation can be accomplished through ad hoc activities by innovating actors in different enabling, directive, and restrictive spaces (Toivonen and Tuominen 2009). In product-centric companies and other organizations for innovation (e.g., consultant firms or organizations for applied research) spaces are often structured more or less through models for innovation as assumptions and 
work models for projects and improvement initiatives. Stage-gate models in product development is a common model that today is often influenced by agile work methods (Cooper 2014; Sommer et al. 2015). Spaces and models are implicitly or explicitly guided by assumptions and knowledge of value and benefits from being the target of innovation.

\subsection{Product-based value logic}

SDL was initiated from the distinction between goods-dominant and servicedominant value logics (Vargo and Lusch 2004), which also are embedded in service innovation practices. Using an SDL lens, innovation research and practice, in many cases including service innovation, are largely product-centric (Michel et al. 2008a, b). While SDL does not deny the importance of a goods-dominant logic, it reframes its significance in a wider perspective on value creation (Normann 2001; Vargo and Lusch 2008). We distinguish between these product-centric framings as a G-D logic, which SDL criticizes, and a product logic understood from an SDL point of view. A G-D logic sees value as being embedded in products through successive enriching phases of production, understanding service largely in analogy to product features and from the point of view of the provider and its service innovation activities to enhance its competitive advantage. Value in exchange is a core dimension of value in use for providers in the sense of financial value by receiving payment in return for products. Service is seen as adding value in analogous ways as additional product features.

Product logic from an SDL point of view is, instead, the innovation of capacity required for realizing situated use value (Michel et al. 2008b). Thus, it creates value for customers as a capacity for service, where products and services (service products) are appliances and aids for its situated realization (Grönroos 2006; Gummesson et al. 2010). Products are platforms or carriers of capabilities for service (operand resources), which can be realized in a use context if customers have the requisite skills and resources (operant resources) to realize these capabilities as self-service. This is in many situations the case, where productrelated service innovation can help to enhance fuller use of capabilities through, for example, innovation in user guides, customer support, spare parts provision, maintenance, operative analytics, etc. to enhance the realization of functionality of products. On the whole, this is developed from a product-based value logic. As products are seen as embedding generic capacities, the innovation order of first the product then the service innovation in industrial companies is logical. A dominant innovation orientation is inside-out from provider capabilities and core technological competences to be embedded in products and additional services to support its functionality in use.

\subsection{Service-based value logic}

Service logic in innovation focuses directly on enhancing customer processes of experience and purposes enabling enhanced situated value in use context for customers (Grönroos and Helle 2010). Thus, service processes are the primary 
focus, with enabling products and services brought together if needed. Service logic changes the focus of understanding innovation from transactional to relational (Normann 2001; Michel et al. 2008a) and to value enhancing in use context. The placement and structure of innovation tends to be more outside-in in a customer context, with a focus on solutions and outcomes enhancing realized customer value. This requires stronger knowledge development and involvement in understanding customer purposes, processes, and experience in the service scape where value emerges in situated use (Bitner 1992; Kristensson et al. 2004; Ostrom et al. 2010; Chirumalla 2013, 2016). Service logic in service innovation is conditioned to the targeted, optimal, and negotiated balance of service co-production and co-creation between the enabler and the user, how the service risks are distributed among them, and the additional service providers involved.

\subsection{Virtual-based value logic}

An additional value logic emerging in digitalized and virtualized service innovation is focused on intelligence and "smartness" based on the information process capacity of information communication technology (ICT). According to Lerch and Gotsch (2015), information technology (IT)-enabled servitization moving towards digitalized productservice systems develops intelligence with the "potential to improve performance and efficiency significantly, which leads to far-reaching competitive advantage" (Lerch and Gotsch 2015, p. 50). Intelligence has several meanings. A common understanding, according to Legg and Hutter (2007), is "an agent's ability to achieve goals in a wide range of environments", thus enabling purposefulness in situated action (von Mises 1949). The improvements to information processing in ICT contribute significantly to making actors, things, activities, and their interaction in service processes more intelligent, thereby enhancing the value co-creation potential. In addition, ICT can take an operant role (Akaka and Vargo 2014) as value creation agents in these humanmaterial networks (Latour 2005). Virtualization makes value creation processes more independent of time and place (Rayport and Sviokla 1995), flexibly extending intelligence into situated purposeful judgment, as Aristotelian phronesis (practical wisdom) to enhance alertness and accuracy in value creation (Kirzner 1997). There is a rich set of norms and models for innovating service emerging from the ICT sector that can be taken advantage of, like service-oriented architecture, agility, data mining, big data analytics, artificial intelligence, machine learning, and more.

From an SDL framing perspective, one issue is how this value enhancing potential is understood and pursued in service innovation, e.g., who and what is made smarter through ICT such as products/services, providers, or customers (Michel et al. 2008a). SDL emphasizes the value of situated intelligence in each specific context to create the best value according to the beneficiary. A productcentric understanding of digital service innovation as emanating from a "digital brain" that can deliver value (cf. Lerch and Gotsch 2015) can be distinguished from a more service-centric understanding that focuses on ICT as enabling beneficiaries' "brain power" to act purposefully to enhance value creation in situated use. Virtual logic from an SDL perspective is virtually distributed intelligence enabling enhanced value in the context of use through situated, synthetic judgment. 
Considerable options for value enhancement have been created and will continue to be created using the virtual flow and reality enabled by ICT technology, its fastincreasing information processing, and its interfaces with the physical world (Rayport and Sviokla 1995; Porter and Millar 1985; Barrett et al. 2015). We are still in the initial stages of virtual service innovation, which also has considerable disruptive implications that must be considered (Michel et al. 2008a, b).

\subsection{Systemic-based value logic}

Systemic value logic that also has a link to recent SDL developments and research can be discerned (Vargo and Lusch 2011; Lusch and Nambisan 2015) based on recognizing the interconnectedness of value and service in different situated uses and its initiation through service processes. Service innovation as a systemic value sees actors as collaborating to jointly discover and create value in ecosystems (Vargo et al. 2015; Lindhult and Hazy 2016). This is based on developments in service and business network research that is pointed towards an emerging interactive business logic in value-creating systems that enable new value constellations in ecologies of complementary actors co-innovating in service networks (e.g., Normann and Ramirez 1993). This interactive business logic is enabled by ICT-supported virtual flows and interfaces that link together actors, activities, and resources in effective and efficient value constellations (Rayport and Sviokla 1995; Porter and Millar 1985). Interactively innovated synergies in valuecreating systems develop density in value creation (Normann 2001), requiring systemic innovation that targets value beyond or in advance of product and service specifications where collaborating actors co-innovate mutually enhanced value. Platforms, which are still expanding today and are considered by some to be part of a platform revolution, are a way to enable densities in interaction to co-create value and innovate to enhance synergies and network effect in value co-creation (Gawer and Cusumano 2014; Cenamora et al. 2017). Platforms are both internal to companies enabling coordinated innovation, and external linking to actors in the business ecosystem (Gawer 2009). Platforms, as part of networked service innovation (Eloranta and Turunen 2016), have considerable potential. However, they also raise challenging issues of information security, rights, and value sharing, which has crucial implications for viable and sustainable business models and value innovation in networked service innovation. Innovation in such a context needs to be truly systemic and synergistic to realize ecosystem potential for value co-creation in service innovation (Vargo et al. 2015; Toivonen 2016; Midgley and Lindhult 2017).

\subsection{Summary}

Table 1 summarises the four value logics for service innovation in a theoretical model. The theoretical model highlights the key characteristics of each value logic and the key differences among them. The key characteristics of each value logic are mentioned in the form of: source of value, offer method, and dominant innovation orientation. 
Table 1 The theoretical model summarises four value logics for service innovation and their key differences

\begin{tabular}{|c|c|c|c|c|}
\hline & $\begin{array}{l}\text { Product- } \\
\text { based logic }\end{array}$ & Service-based logic & $\begin{array}{l}\text { Virtual-based } \\
\text { logic }\end{array}$ & Systemic-based logic \\
\hline $\begin{array}{l}\text { Source of } \\
\text { value }\end{array}$ & $\begin{array}{l}\text { Value in } \\
\text { capacity }\end{array}$ & $\begin{array}{l}\text { Value emerging } \\
\text { in situated use }\end{array}$ & $\begin{array}{l}\text { Value in virtual, } \\
\text { distributed } \\
\text { intelligence }\end{array}$ & $\begin{array}{l}\text { Value emerging in } \\
\text { interaction between } \\
\text { use and enabling } \\
\text { contexts }\end{array}$ \\
\hline $\begin{array}{l}\text { Offer } \\
\text { method }\end{array}$ & $\begin{array}{l}\text { First product, } \\
\text { then } \\
\text { services, } \\
\text { then } \\
\text { services as } \\
\text { add-ons }\end{array}$ & $\begin{array}{l}\text { Solution focus, service is } \\
\text { the primary focus, with } \\
\text { enabling products } \\
\text { brought on line if } \\
\text { needed }\end{array}$ & $\begin{array}{l}\text { Intelligence } \\
\text { embedded in } \\
\text { both product } \\
\text { and service } \\
\text { processes }\end{array}$ & $\begin{array}{l}\text { Interactive, systemic } \\
\text { innovation targeting } \\
\text { value beyond or in } \\
\text { advance of product } \\
\text { and service } \\
\text { specifications }\end{array}$ \\
\hline $\begin{array}{l}\text { Dominant } \\
\text { innovation } \\
\text { orientation }\end{array}$ & $\begin{array}{l}\text { Inside-out } \\
\text { from } \\
\text { provider } \\
\text { capabilities }\end{array}$ & $\begin{array}{l}\text { Outside-in from } \\
\text { customer context }\end{array}$ & $\begin{array}{l}\text { ICT system } \\
\text { development; } \\
\text { develop } \\
\text { phronesis } \\
\text { from } \\
\text { information }\end{array}$ & $\begin{array}{l}\text { Interactive, co- } \\
\text { innovation }\end{array}$ \\
\hline $\begin{array}{l}\text { Related } \\
\text { references }\end{array}$ & $\begin{array}{l}\text { Cooper } \\
\text { (2014), } \\
\text { Vargo and } \\
\text { Lusch } \\
(2008)\end{array}$ & $\begin{array}{l}\text { Vargo and Lusch (2004), } \\
\text { Grönroos and Helle } \\
\text { (2010) }\end{array}$ & $\begin{array}{l}\text { Rayport and } \\
\text { Sviokla } \\
\text { (1995), Porter } \\
\text { and Millar } \\
\text { (1985) }\end{array}$ & $\begin{array}{l}\text { Normann (2001), Vargo } \\
\text { et al. (2015) }\end{array}$ \\
\hline
\end{tabular}

The resulting theoretical model specifies and widens the space for service innovation, bridging the gap between SDL as a meta idea and as a practice. The SDL is mainly viewed from both product and service logic perspectives. However, SDL theory so far has not been extended beyond these two views, especially with insights from the empirical data. Based on our literature review and practical experiences from the case company, this study discovered the possibility of having two additional logics, virtual and systemic, for service innovation. These additional logics have not been discussed often in the literature. In the extant literature, we have found limited theoretical reasoning on the latter two logics, especially with empirical data-based insights. Moreover, there is a need to study the potential opportunities and challenges with different value logics in the context of service innovation orientation, especially along the four value logics.

\section{Research method}

The research approach was interactive and interpretative, with a focus on mutual learning and co-production of knowledge pooling expertise from academia and industry (Svensson et al. 2007). A constructive-pragmatic view on science (Bradbury 2015) was a point of departure, where construction and reconstruction of practices and conceptual understanding can interact with experiential learning 
and reflection. During such interaction, the significance and consequences of these constructive efforts were experimentally assessed and discursively validated. Thus, a core dimension in this research was the exchange of information and dialogue between service innovation researchers from universities and practitioners at the partner company who are involved in servitization activities (i.e., product and service innovation) and its management, building on a tradition and methodology of dialogic action research (Gustavsen 1992). Open conversations on equal terms were occasions for exchange, mirroring and confrontation of different understandings, and spurring processes of individual, mutual, and joint learning providing a source for knowledge creation (Nonaka and Takeuchi 1995).

The dialogue between people with different expertise, positions, and experiences was central for the framing process. Framing (Dewey 1939; Schön 1983; Schön and Rein 1994) includes sense making, developing an overarching understanding of the journey, conceptualization, imaginative thinking, using established conceptual resources from scientific research, and a preunderstanding of participants. It is abductive (Pierce 1955) in taking a creative leap to a working hypothesis/framing and iterating between the hypothetical framing and the funding of experience and data. This process also was inspired by the hermeneutical circulation between the whole and its parts and between preunderstanding and new, emerging understanding (Gadamer 1975; Alvesson and Sköldberg 2009). This iterative and circular process was repeated until the framing was settled, stabilized, and discursively validated. The framing of research in this study is illustrated in Fig. 1.

\subsection{Case companies}

The context in this study was a longitudinal (3 years) research project involving Ericsson and $\mathrm{ABB}$ Process Automation shifting towards servitization to improve their service offerings and service innovation conditions. The goal of the project

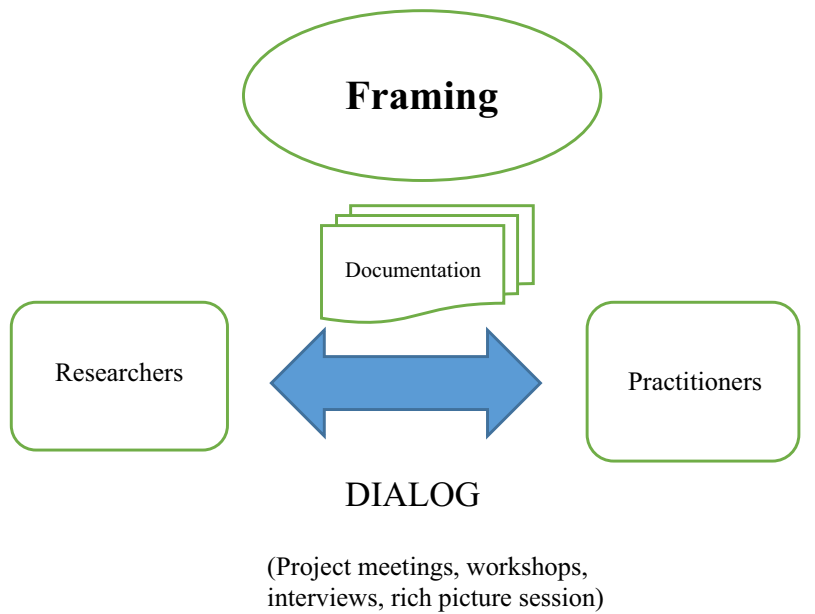

Fig. 1 The constructive research of framing the experience of the innovation journey 
was to increase the understanding on servitization and to identify ways of working with the servitization.

Ericsson is a global leader in ICT solutions, with approximately $40 \%$ of the world's mobile traffic carried over Ericsson networks. They operate in over 180 countries and offer solutions from cloud services to network design and optimization. Ericsson has increasingly focused on servitization through building its professional services business, which provides consulting, customer support, network design and integration, and training, as well as managed services such as application hosting and network operations oversight.

$\mathrm{ABB}$ Process Automation (ABB), which is one of the five business divisions in $\mathrm{ABB}$, focuses on products and solutions for instrumentation, automation, and optimization of industrial processes. Specifically, the focus was on the investigation of a digitalization-driven new service innovation, MCS, which is a new web-based service delivery platform that is one of the flagships of the company's recent servitization initiatives. Through this platform, new service offerings are made visible and accessible to end users, including free services, services available through service contracts, and additional services that can be ordered by the user. In 2015, the company had a presence in 62 countries with ABB users and 48 countries with end users. Their user base includes 1475 ABB users, 1724 end users, and 2028 registered control systems (hereafter referred to as customers).

A core constructive focus at $\mathrm{ABB}$ has been on the framing of the service innovation situation in the company, with a particular focus on leading development on web-based platforms for service delivery and innovation, namely MCS, which links the company and its service organization directly to its customers. The MCS project can be seen as a probe into service innovation conditions, and has also been instrumental in "provoking" these conditions and to some extent changing and improving them. From a research point of view, it is thus interesting to understand its innovation journey (Van de Ven et al. 1999) in confronting and generating embedded assumptions and understandings of service. Its innovation was framed as the case story for this research and was important in the development and grounding of the earlier presented theoretical model.

\subsection{Research process and data collection and analysis}

The study conducted constructive research activities in the framing process as shown in Fig. 2. Research emphasis moved from left to right in the constructive activities, with an iterative to and from movement between the activities. First, a series of semi-structured interviews (Yin 2009) were done with professionals involved in and responsible for service innovation to understand the character and conditions for servitization in the two manufacturing companies. This empirical data provided a better basis for the contextual understanding of actual conditions and developments. In addition, the research work was grounded in dialogue with representatives from both companies in different forms, including project meetings, workshops, and a rich picture session (Checkland and Poulter 2006).

In the second phase, one of the flagships of recent servitization, MCS, was studied. The focus here was on constructing the MCS development story. Hence, 


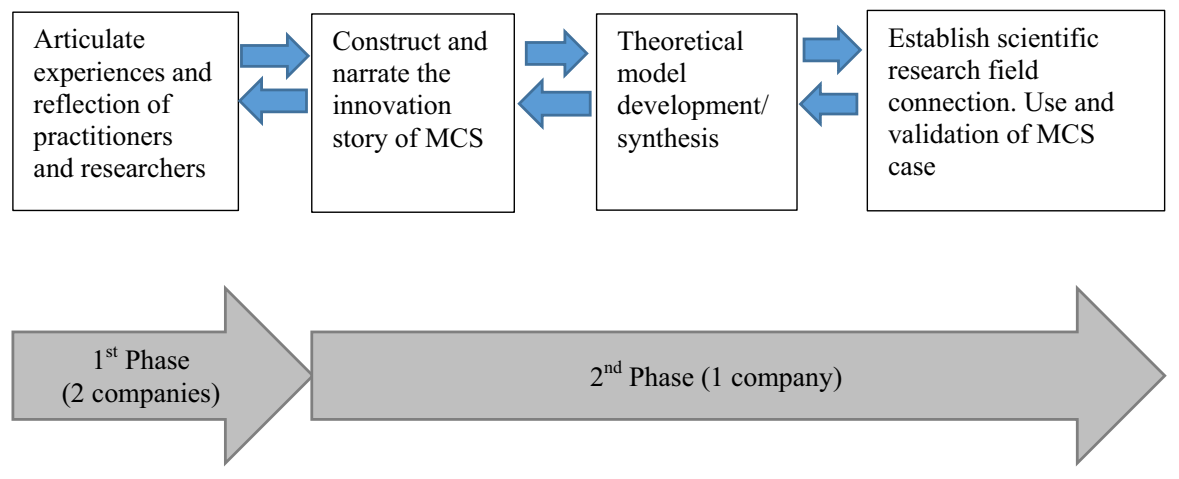

Fig. 2 Constructive research activities in the framing process

additional conversations and interviews were done with the leading entrepreneur and sponsor to collect more detail information on the MCS innovation journey. Data coding (Miles et al. 2013) was done through identification of critical episodes and statements from the dialogue and documentation in relation to the emerging framing of the journey. The theme of a service innovation space shift was focused and deepened, resulting in the story synthesized in Fig. 3. In total, data were collected through six project meetings and workshops, 23 interviews, and one video-recorded rich picture session. The interviewed participants were involved in different functions (e.g., product development, business development, service innovation, aftermarket management, sales, and marketing) within the company.

The third phase was the conceptualization of the theoretical model (see Table 1) by integrating the relevant research on service innovation and SDL, leading to the identification of four different value logics for service innovation. In the fourth phase, the connection and validation in the research field was further deepened. Validation was achieved in the coherence and fit between results from the interrelated activities. The activities and the movement between them was guided by the preunderstanding, research interests, and points of view of those involved, both academic and practitioner. A common research interest was servitization, with a focus particularly on the condition for service innovation and its potential improvement. One academic interest was to develop a theory and practice for innovation that is driven by an understanding of value, the so-called value-driven innovation (e.g., de Ana et al. 2013; Lindhult et al. 2015), where SDL is one source of inspiration along with systems and complexity thinking (Goldstein et al. 2010).

The next section describes the innovation story of MCS, including both elucidation of the journey and the application of the theoretical model. The story is presented as follows. First, the MCS journey is presented with the critical episodes. Second, the shift towards IS and service-oriented innovation models are explained. Third, the movement of the MCS case between different value logics (and spaces) is depicted and explained. 
Launch of Automation Sentinel Lifecycle Management Support program to serve installed base and develop service support business in the face of tougher competition in product sales.

Insight by leading innovators on the need for a virtual platform to bridge the distance to customers through a lifecycle support program.

Spring

Pre-study financed from aftermarket with external Microsoft-certified IT consultants. Introduced an agile approach to develop a web-based service portal based on Microsoft SharePoint.

Decision and commitment from new control technology service segment for development budget.

Alliance building to support working with IS/agile/outside-in innovation modela paradigmatic shift.

Build-up of loose, cross-functional innovation teams coordinated by a leading entrepreneur in the portal and service development work.

Nov

Integrating information to create value for customers via web services. Delay to solve information security in accessing internal $\mathrm{ABB}$ information on the cloudification road.

Registration procedure solution for access control is in place. Intensive innovation for enhancing efficiency, convenience, and value for channels, customers, and administrators in platform use.

Launch with broader engagement of ABB channels and customers on webinars and process automation conferences.

Scale up of customer and channel participation and facilitate ongoing interactive service development.

Initiative to develop MY ABB web portal for a single online entry to customer/user with using experiences from MCS in a leading role.

Platform-thinking approach to creating new services. Initiative to open the platform to external channel partners.

Fig. 3 Critical developments in the journey of MCS

\section{The story of My Control System (MCS)}

\subsection{MCS journey}

In the face of tougher competition with lower margins on product business, the case company realized that there is a need for a new strategy for extending the service life of the installed process control systems base. Typically, a control system will 
require software function licenses, up-to-date malware protection, system diagnostics, maintenance support, training modules, safety monitoring reports, and so on.

In the aftermarket organization, a group of professionals saw the considerable distance from the original company to its customers, and initiated informal initiatives based on bridging that distance through a web-based platform. This platform could act as a virtual channel to customers to package services and bring relevant information and analytical services such as system checks, updates, and upgrades to customers virtually. By looking at how other companies-such as banks, IT companies, and automobile manufacturers-were working, a new business model was developed based on the popular Canvas model (Osterwalder and Pigneur 2010). With the deployment of more service-oriented ideas, methods, and tools (such as direct dialogue with customers and channels, identification of personas and user stories, and mock-ups of interfaces and web services), a journey of servitization was initiated in the aftermarket organization. Through building a loosely coupled innovation team consisting of people with different professional tasks in and outside of $\mathrm{ABB}$, including a business development manager as a principle entrepreneur and an aftermarket manager as a sponsor, a formal project was developed. However, the project was challenged because the R\&D development resources were not available, and the R\&D innovation model was not suited for this specific project. Subsequently, the project changed its arena to a more flexible IS innovation model and employed the agile methodologies of scrum and sprints, which were more suitable to web-based service development. In 2012, the MCS was successively developed, launched, and disseminated widely among sales channels and customers. Figure 3 gives an overview of critical events and activities in MCS's development. Eventually, MCS became a vehicle for the development of a lifecycle management support program, called Automation Sentinel, for distributed control systems. ABB's MCS web application provides control system customers with a means of keeping track of many aspects of their system, such as maintenance information, upgrades, and software delivery times. It brings the customer closer to $\mathrm{ABB}$ and $\mathrm{ABB}$ closer to the customer, aiming at a solid, longterm and mutually beneficial business relationship.

\subsection{Shift towards information systems and service-oriented innovation models for MCS}

In the MCS development journey, a crucial feature in addressing the challenges of bridging the distance to customers was the shift away from the established stagegate model of product innovation used by the R\&D organization. As MCS is not a product and the driving actors in the aftermarket organization was formally outside the R\&D organization, development resources from R\&D was difficult to access. In addition, the main intrapreneur saw having $\mathrm{R} \& \mathrm{D}$ control the project as dangerous for its success. So, it was necessary to access other resources to develop the platform outside $\mathrm{R} \& \mathrm{D}$. In a large corporation such as $\mathrm{ABB}$, it is important to create legitimacy using some already available innovation models for project control.

The development of a web-based central information systems (IS) application implied quite different tools and methodologies for implementation; it was also 
another type of development than what R\&D had traditionally been doing. The IS model provided greater flexibility in the sense that the execution of the project and the stage-gate checkpoints were a bit more freely set up, which opened up (at that point in time) a doorway to a new approach with agile and scrum methodology. The agile-oriented work supported the interaction and collaboration with customers during the service innovation and platform development, which has been emphasized in service innovation research (Kristensson et al. 2004). The leading intrapreneur was particularly focused on this customer interaction during development using personas and associated customer stories as an alternative to the traditional focus on product specifications, as well as concrete business cases developed based on the business model for the platform.

Figure 4 typifies the shift of MCS as a movement in relation to service innovation practices related to: product- vs. service-oriented service innovation, and physical vs. IT/virtual innovation. In Fig. 4, the main shift in the MCS innovation approach is illustrated as a movement from IT-based products (from a position within the product-oriented and physical quadrant) to the MCS platform in 2015 (to a position within the product-oriented and IS/virtual quadrant).

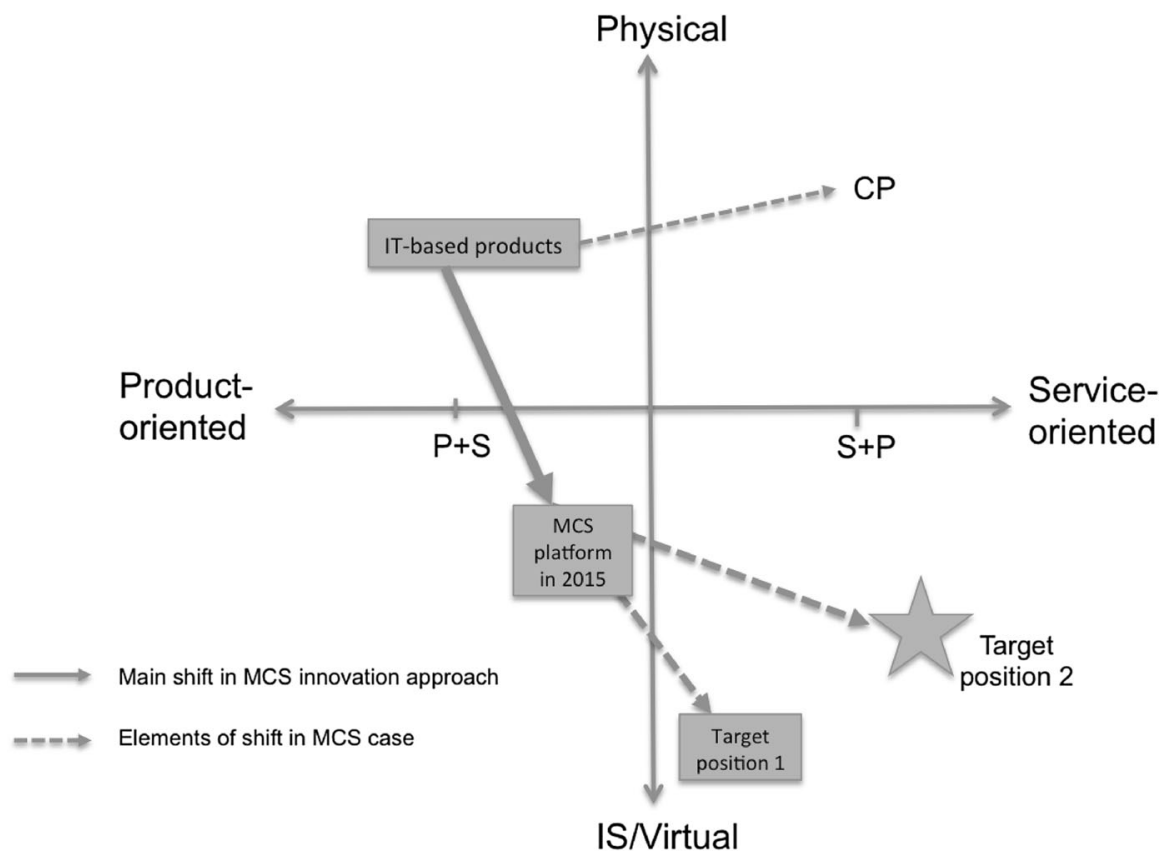

Fig. 4 The shift in the course of MCS's development is illustrated in relation to: product- versus serviceoriented service innovation, and physical versus IT/virtual innovation. The shift is shown in arrows, representing different value spaces and logics for MCS's service innovation. CP stands for complimentary position. $\mathrm{P}+\mathrm{S}$ stands for products plus services, and $\mathrm{S}+\mathrm{P}$ stands for services plus products. The ITbased products position refers to product-based value logic, the MCS platform 2015 position refers to service-based value logic, the Target position 1 refers to virtual-based logic, and the Target position 2 refers to systemic-based value logic 
Another important movement in service innovation, which could be brought into the context of a more flexible IS gate model, was the focus on the landscape of service operation, where control system products are used and the services related to them are co-created with customers, sales channels, and the ABB aftermarket organization (which is illustrated in Fig. 4 as target position 1). The latter dimension shows a crucial difference from established industrial product innovation models and practices (e.g., Cooper and Edgett 2009). The struggle to institute this shift in industrial innovation practice was a core challenge of the servitization encountered - an important dimension in shifting the mindset and DNA embedded in productcentric innovation practices. An outside-in approach taking a point of departure in the landscape of service operation, the service scape (Bitner 1992), or service system embedded in customer context (Chandler and Vargo 2011) is a crucial feature of truly service-oriented innovation.

The MCS project also initiated a move towards a service agility approach, where service innovation is incorporating information from providers, customers, and channels, thereby enabling internal and external actor network orchestration (target position 2 in Fig. 4). It was agile in taking a point of departure in the interaction between providers, customers, and channels. It is important that interfaces work and provide different values for different participants so that they also contribute with their resources and efforts in the co-creation. The typification in Fig. 4 is much messier in actual industrial innovation practices where different approaches intersect, overlap, and hybridize. For example, the trend in R\&D to incorporate agile methodology in stage-gate models is also evident at ABB (e.g., Sommer et al. 2015). Going towards services and virtualization (i.e., virtual-based value logic) in a product-centric industrial setting implies challenges, as the story of the MCS case shows. A service agility approach needs to be placed in interaction and collaboration with other existing approaches in the company.

\subsection{Different value logics for service innovation in the MCS development}

An important dimension in widening the space for service innovation is to harness different logics to drive innovation using source of value (see Table 1). In the MCS case, there was a move to harness service-based logic for innovation in the sense of an outside-in orientation with a stronger point of departure in a value potential in use context, for example, by interacting with pilots or lead customers in development. In this case, the central position of the aftermarket group outside the regional service organizations did not want to "take over" the contact from "the channels", but instead develop a tool useful for their work. Thus, outside-in service innovation was not the main focus of the MCS project (i.e., service-based logic). Instead of providing more generic tools and capacities through MCS, it enabled customers to create value for themselves together with appropriate channel actors.

The main focus was on virtualization with a source of value that emerged in the form of virtual, distributed intelligence (i.e., virtual-based logic). In building an ITenabled platform as a basis for service innovation, a virtual space was entered wherein value can be liquefied (Normann and Ramirez 1993) when created across time and space, particularly where it is possible to virtually access services and 
servitized products, such as software updates or maintenance checks. Thus, service innovation is virtualized in creating value through virtual, distributed intelligence from simple information sharing to big data analytics (i.e., refer to the "MCS platform 2015" box and target position 1 in Fig. 4). In the case of MCS, this type of service innovation mainly adds value to service agreements, but it is also available as a service for a fee. Here, service innovation needs to be integrated with product innovation (e.g., embedding sensing capabilities that check the health of the products for an environmental data in use context) and guided by appropriate business models through value propositions that can pinpoint important customer benefits as profit formulas.

We also observed that, in the context of MCS, the case company was heading towards systemic-based logic (i.e., target position 2), where MCS can function as a platform for customer-partner interaction in discovering and creating new value together. The organizational roles and responsibilities for managing and developing different service products were developed in addition to MCS as an information channel to the customers. The ambition was to open the platform to external channel partners (2017-2018) to provide the basis for service agility in continuously updating existing services while discovering and creating additional ones. The platform has thus initiated a journey wherein the platform can be an increasingly forceful tool in a systemic-based logic of service innovation where the network of actors can co-innovate to create mutual value, thereby enhancing the total value in the form of a co-creating network.

Through the analysis of the MCS journey, we observed that MCS can target different positions in the landscape of different value logics, as shown in Fig. 4 and Table 1. A more service-capacity-oriented approach where MCS provides more of generic, also automatized, affordance for customers and other actors in selforganizing value creation (i.e., target position 1; virtual-based logic) can be seen as the present direction. Otherwise, a more network-oriented approach where the platform is more focused on interactive service innovation where different parties can jointly discover value (i.e., target position 2; systemic-based logic) would be adopted. Network orientation needs to deal with the complexity of multiple interactive parties and stakeholders, and this constellation can engage in coinnovation.

\section{Discussion: potential opportunities and challenges with different value logics}

Based on the theoretical model and empirical insights from the MCS case journey, we find that there are significant opportunities for companies to enhance service innovation using each source of value and each of the value logics, as well as using hybrid forms between them. The MCS journey reflects the trends towards servitization and digitalization in the process automation industry using the webbased service platform. One motivation to develop the MCS platform instead of delivering them as separate packages is to allow customers to continuously download the software/service features and use MCS as a core platform. In this way, 
products are servitized and continuously have access to service features. In addition, the platform itself provides an additional way for the company to engage with customers, which could lead to new service innovations, as many of the ideas, according to the managers, are generated when customers are using the portal. Consequently, customer reflections give the managers great business ideas, thereby creating opportunities to create more value. Service innovation traditionally has been an after-thought to products. The point of the MCS case is to show how to efficiently widen the space for service innovation in a product-centric company using different value logics.

The MCS journey is narrated as a space shift in understanding service innovation and its models, implying different kinds of value logics in efforts to enhance value. It contributes to the literature in expanding the understanding of value logics for service innovation (Vargo and Lusch 2004; Lusch and Vargo 2014), pointing to a broader spectrum to be harnessed in service innovation. It is in general agreement with SDL research (Vargo and Lusch 2004) in recognizing value as emerging in situated use determined by the beneficiary. But it also recognizes the different logics of innovating to enhance value.

However, by examining the contextual aspects of the MCS, we identified further insights in its servitization journey guided by different value logics. Accordingly, each value logic not only has advantages but also has limitations, risks, and challenges-what we pinpointed as "complexity traps" and "service gaps". These challenges are synthesized and exemplified in Table 2. Complexity traps are domains of innovation, which are sources of limits of understanding and, therefore, in realizing value-enhancing service processes. This results in service gaps, in the sense of limits in actors' abilities to realize value creation in use.

A significant advantage of the product-based logic of service innovation is in creating generic capabilities that support the value creation of beneficiaries themselves or in interaction with enabling actors. As the necessity of service innovation capabilities is less of a focus in this logic, there is a risk of a complexity trap (i.e., product complexity), where the advanced service capabilities embedded in products, processes, or resources outrun the beneficiaries' capacity to create value in use from those capabilities. This could lead to a service gap (i.e., customer realization of value capacity) in customer operations, where channels or customers are not able to co-create value in the customer context. This means that there is a

Table 2 Challenges in service innovation guided by different value logics

\begin{tabular}{clccc}
\hline & Product logic & Service logic & Virtual logic & Systemic logic \\
\hline $\begin{array}{c}\text { Complexity } \\
\text { trap }\end{array}$ & Product complexity & $\begin{array}{c}\text { Competence } \\
\text { complexity }\end{array}$ & $\begin{array}{c}\text { Information } \\
\text { complexity }\end{array}$ & $\begin{array}{c}\text { Relational } \\
\text { complexity }\end{array}$ \\
Service gap & $\begin{array}{c}\text { Customer realization of } \\
\text { value capacity }\end{array}$ & $\begin{array}{c}\text { Contextualization of } \\
\text { value creation }\end{array}$ & $\begin{array}{c}\text { Situated } \\
\text { synthetic } \\
\text { judgment }\end{array}$ & $\begin{array}{c}\text { Mutual synergy of } \\
\text { service value }\end{array}$ \\
& & & & \\
\hline
\end{tabular}


sense of limits in resources (e.g., competence) on the customer's side, which limits the full exploitation of the capabilities to create value.

Service-based logic is focused on enhancing situated value in use for beneficiaries. A core advantage is that service innovation, in line with SDL, is fully targeting value in use and in context, and should ideally lead to optimal value. But as an innovation logic, it is at risk of reaching a complexity trap (i.e., competence complexity) in targeting too-diversified customer contexts requiring broad competencies in innovating customized solutions and outcomes. For example, in the case of ABB Industry Automation's steering equipment, the contextual knowledge required of varied industries sets a limit to viable and profitable service innovation. There is, thus, a service gap (i.e., contextualization of value creation) that emerges because of limits in knowledge (and resources) to fully contextualize value innovated in use (outside-in).

Virtual-based logic enables service innovation through broadly accessible information and analytics that supports actors in recognizing and enhancing situated value in use. The MCS platform here is part of a digital industrial revolution, which has enormous potential for supporting actors' intelligence in value creation. At the same time, there are complexity traps (i.e., information complexity) in connecting different information sources and synthesizing contextually relevant information to support value creation in each use context. This leads to a service gap (i.e., situated synthetic judgment) in the sense of too much (information overload), incorrect, or unspecified information for customers to make correct value judgments.

Finally, systemic-based logic enables service innovation through taking advantage of differences in valuation and resources among actors in the ecosystem. The processes of joint value discovery can widen mutual awareness of what different parties can do for each other and, in association, provides a basis for co-innovation. The more actors mutually learn and expand their awareness, the more opportunities for synergistic value creation can be discovered. In the MCS case, this space/logic for service innovation is in its initial stage. There is also a complexity trap (i.e., relational complexity) in enabling effective co-innovation among multiple stakeholders, where issues of conflict and sharing of value is a challenge. This results in service gaps (i.e., mutual synergy of service value) in the sense of uneven creation and sharing of value, which may cause some actors to refrain from contributing important resources to the value-creating system.

Overall, our empirical research has pointed to the need to clarify the connection through the development of a theoretical model to link value logics to situated service innovation practices. This is a contribution to the SDL call for mid-range theories that can connect the meta-framework with compatible, more actionable frameworks and tools that "not only bridge S-D logic and practice, but also provide a bottom-up support for S-D logic at the same time" (Lusch and Vargo 2014, p. 204; Brodie et al. 2011). The theoretical model was developed bottom-up from empirical, practice-based research and is expanding the understanding of value logics, thus specifying and amending SDL as a theory of value creation and service innovation. We defined value logics for service innovation as ways to understand and pursue enhanced and new value in service innovation embedded in situated spaces and 
practices. Because of important differences in ways to understand value creation and pursue service innovation and servitization in practice, we framed four different value logics that specify and expand the two original SDL logics. Thus, this work contributes to the open issue on how to fruitfully typify and categorize service innovation as processes and practices from an SDL view. The categorization based on orientations of different understandings of value and value creation potentials and how they are realized in practice is useful both for theory and practice. The theoretical model provides a theoretically distinct point of departure in SDL and explicitly links it to service innovation practices (Edvardsson and Tronvall 2013). It also furthers the SDL and innovation research agenda on the role of microinstitutions to enhance value creation in service innovation in different spaces.

\section{Conclusions and future work}

This paper developed a theoretical model for understanding service innovation as pursued in different spaces governed by contextual factors such as resources, norms, and innovation models. This is a less-developed theme in service innovation research, which we believe deserves more attention. A contribution was made to the discussion of value logics in service innovation, showing that product- and servicebased logic focuses in SDL can be complemented by virtual- and systemic-based value logics, thus expanding the areas where service innovation can create value. Thus, the findings enrich and amend SDL as a perspective on service and value in relation to innovation activity. The focus of SDL on value in context can also be expanded to consider service innovation in the context of various spaces. We believe the theoretical model opens up a number of questions that have significant implications both for theory and practice. For example, what are the characteristics of different spaces for service innovation? How can spaces be created so that they are conducive, effective, and efficient for different value logics? How are different spaces related? How are they coordinated, hybridized, and integrated?

As research findings were emerging from the study-related dialogue with practitioners, both theoretical and management implications and recommendations in relation to service innovation and servitization were also generated. First, companies should focus on value in context for different parties choosing suitable value-based innovation orientation, but watch for complexity traps and service gaps of different logics. This is the core recommendation from our research findings. The theoretical model presented in the paper may be used as a guide. The mundane point is that companies should not develop something that is not valuable and profitable to the customer, providers, and other contributing actors in the value network. Second, based on the actors' in-depth understanding of value in context, use business model development as a pedagogic tool and boundary object for developing a shared understanding and bringing all actors on board in a journey towards enhanced mutual benefits. This was emphasized in the MCS case and is in accordance with process-oriented business model research literature (e.g., Sosna et al. 2010). Our findings add that business model learning is also helpful for explicating value logics in the context of innovation and for considering which logic 
or hybrid logic is most suitable in a specific situation. Third, challenge your productcentric DNA in the organization and its network to take advantage of the potential for value creation that is created by SDL thinking and deployment. This is in line with recent understandings of service innovation as institutions and as institutionalized practices (e.g., Vargo et al. 2015; Edvardsson and Tronvall 2013). Our research adds to the literature by emphasizing the importance of micro-institutions (e.g., as embedded in the used innovation models) in enabling, directing, and restricting innovation. This requires the development of strong cultural and thought leadership and, as our findings add, creating enabling spaces and environments to nurture innovation through different value logics. This leads to a fourth recommendation to breed innovation guardians as institutional entrepreneurs to protect and support the new ways of working in the company and leading change in the organization towards a more supportive environment and processes for service innovation. Innovation practices in companies are more or less institutionalized in thinking and in their practices of different spaces as our research indicates. Then, sufficiently empowered institutional entrepreneurship (e.g., Lounsbury and Crumley 2007) is required to, using Lewin's well-known change management metaphor (Lewin 1947), unfreeze the existing situation, transform conditions for innovation, and then refreeze it in a modified or new institution. This might also involve moving to or choosing spaces that are more conducive for service innovation. In the MCS case, the leading entrepreneurs chose not to access the resource-rich space traditionally used for technology and product innovation to avoid being forced to use the situated models and specialized competencies in this space, which they considered to be unsuitable for service innovation. Institutional entrepreneurship as a focus in service innovation has received limited attention, but, according to our findings, it is a fruitful future research topic.

The study has several limitations that call for further research on the topic. This research can be considered exploratory in theoretical model development and validation, as it is limited to one empirical study. Broader studies of cases are important for service innovation initiatives and projects, including both qualitative, quantitative, and action-oriented, to widen the possibility for external validation and amendments to the construct. Methodologically, dialogic action research (Gustavsen 1992) can support the usage and testing of the theoretical model and development of practical ways to realize value logics for service innovation, which could eventually lead to value-driven innovation (de Ana et al. 2013; Lindhult et al. 2015), such as in the context of improving service innovation conditions in manufacturing companies to enable servitization. Synthesizing existing research and further development of methods and processes for assessing and measuring value adequate for different logics would also be a fruitful line of research to clarify effective valuation practices for service innovation. Further research on the framework through conceptual studies and literature reviews is also commendable. There are several options. The value logic theoretical model suggests a move beyond a product-service dialectic to a focus on value and value (co-) creation. It might be fruitful to consider "value-dominant logic" as an orientation and driver for innovation in general and service innovation in particular. The dialectic that spurred SDL as a counter paradigm can be synthesized on a new level of understanding, 
namely aufhebung, as Hegel (Gadamer 1976) said, as a mid-range theory of value creation that can inform innovation and operative practice. As value is dynamic and contextual, valuation becomes a fundamental activity in value-driven innovation to jointly discover value in interaction between parties. The character of these processes is a popular topic for future research. An example of another area for conceptual review is the proposal of a virtual value logic, and virtualization as a proposal for depicting this line of service innovation. We believe it is more adequate than "digital" and "digitalization", which is quite a technical way of understanding the service innovation space and dynamics enabled by IT capacities. A conceptualization of intelligence is offered as a value focus in this logic, which we believe is adequate, but we welcome further studies on the value focus on this quite important space for service innovation today and even more so in the future. In particular, the connection between different value logics and the business model innovation and its elements are worth focusing on in future work. Finally, crossbreeding the system, complexity, and innovation fields in research and management of a systemic logic for innovation is still in its infancy and deserves much more attention (cf. Goldstein et al. 2010; Toivonen 2016; Midgley and Lindhult 2017). Systems and complexity leadership and collaboration methodologies in innovation efforts are important areas for further research and experimentation.

Funding Funding was provided by Stiftelsen för Kunskaps- och Kompetensutveckling (Grant No. SIMGIC).

Open Access This article is distributed under the terms of the Creative Commons Attribution 4.0 International License (http://creativecommons.org/licenses/by/4.0/), which permits unrestricted use, distribution, and reproduction in any medium, provided you give appropriate credit to the original author(s) and the source, provide a link to the Creative Commons license, and indicate if changes were made.

\section{References}

Akaka MA, Vargo SL (2014) Technology as an operant resource in service (eco)systems. IseB 12:367384

Alvesson M, Sköldberg K (2009) Reflexive methodology: new vistas for qualitative research, 2nd edn. Sage Publication, London

Anderson JC, Narus JA (1998) Business marketing: understand what customers value. Harv Bus Rev 76 (6):53-65

Baines T, Lightfoot H, Bendettini O, Kay J (2009) The servitization of manufacturing. A review of literature and reflection on future challenges. J Manuf Technol Manag 20(5):547-567

Ballantyne D, Williams J, Aitken R (2013) Introduction to service-dominant logic: from propositions to practice. Ind Mark Manag 40:179-180

Barrett M, Davidson E, Prabhu J, Vargo S (2015) Service innovation in the digital age: key contributions and future directions. MIS Q 39(1):135-154

Bitner MJ (1992) Servicescapes: the impact of physical surroundings on customers and employees. J Mark 56:57-71

Bradbury H (ed) (2015) The SAGE handbook of action research, 3rd edn. Sage, Los Angeles

Brodie R, Saren M, Pels J (2011) Theorizing about the service dominant logic: the bridging role of middle range theory. Mark Theory 11:75-91 
Cenamora J, Sjödin Rönnberg, Parida D (2017) Adopting a platform approach in servitization: leveraging the value of digitalization. Int J Prod Econ. https://doi.org/10.1016/j.ijpe.2016.12.033

Chandler JD, Vargo SL (2011) Contextualization and value-in-context: how context frames exchange. Mark Theory 11(1):35-49

Checkland P, Poulter J (2006) Learning for action: a short definitive account of soft systems methodology and its use for practitioners, teachers and students. Wiley, Chichester

Chirumalla K (2013) Managing knowledge for product-service system innovation: the role of Web 2.0 technologies. Res Technol Manag J 56(2):45-53

Chirumalla K (2016) Organizing lessons learned practice for product-service innovation. J Bus Res 69 (11):4986-4991

Cooper RG (2014) What's next? After stage-gate. Progressive companies are developing a new generation of idea-to launch processes. Res Technol Manag J 57(1):20-31

Cooper RG, Edgett SJ (2009) Successful product innovation: a collection of our best. Product Development Institute Inc., Ancaster

de Ana FJ, Umstead KA, Phillips GJ, Conner CP (2013) Value driven innovation in medical device design: a process for balancing stakeholder voices. Ann Biomed Eng 41(9):1811-1821

Dewey J (1939) Logic: the theory of inquiry. George Allen \& Unwin Ltd, London

Dewey J (2008) The later works, 1925-1953, vol 13: 1938-1939. Experience and education, freedom and culture, theory of valuation, and essays. Carbondale: Southern Illinois University Press

Edvardsson B, Tronvall B (2013) A new conceptualization of service innovation grounded in SD logic and service systems. Int J Qual Serv Sci 5(1):19-31

Eloranta V, Turunen T (2015) Seeking competitive advantage with service infusion: a systematic literature review. J Serv Manag 26(3):394-425

Eloranta V, Turunen T (2016) Platforms in service-driven manufacturing: leveraging complexity by connecting, sharing, and integrating. Ind Mark Manag 55:178-186

Fischer T, Gebauer HY, Fleisch E (2012) Service business development. Strategies for value creation in manufacturing firms. Cambridge University Press, Cambridge

Fundin A, Witell L, Gebauer H (2012) Service transition: finding the right position on the goods-toservices continuum. Int J Modell Operat Manag 2(1):69-88

Gadamer H-G (1975) Truth and method. Crossroad, New York

Gadamer H-G (1976) Hegel's dialectic. Yale University Press, New Haven

Gawer A (2009) Platforms, markets and innovation. Edward Elgar, Cheltenham

Gawer A, Cusumano M (2014) Industry platforms and ecosystem innovation. J Prod Innov Manag 31 (3):417-433

Gebauer H, Krempl R, Fleisch E, Friedli T (2008) Innovation in product-related services. Manag Serv Qual 18(4):387-404

Goldstein J, Hazy J, Lichtenstein B (2010) Complexity and the Nexus of leadership. Leveraging nonlinear science to create ecologies of innovation. Palgrave Macmillan, Basingstoke

Grönroos C (2006) Adopting a service logic for marketing. Mark Theory 6(3):317-333

Grönroos C (2012) Conceptualising value co-creation: a journey to the 1970s and back to the future. J Mark Manag 28(13-14):1520-1534

Grönroos C, Helle P (2010) Adopting a service logic in manufacturing: conceptual foundation and metrics for mutual value creation. J Serv Manag 21(5):564-590

Gummesson E (2008) Extending the service-dominant logic: from customer centricity to balanced centricity. J Acad Mark Sci 36:15-17

Gummesson E, Lusch RF, Vargo SL (2010) Transitioning from service management to service-dominant logic. Int J Qual Serv Sci 2(1):8-22

Gustafsson A, Kristensson P, Schirr G, Witell L (2016) Service innovation. Business Expert Press, New York

Gustavsen B (1992) Dialogue and development. Theory of communication, action research and the restructuring of working life. Van Gorcum, Assen

Holbrook MB (1994) The nature of customer value. In: Rust RT, Oliver RL (eds) Service quality: new directions in theory and practice. Sage Publications, Thousand Oaks, pp 21-71

Kirzner I (1997) Entrepreneurial discovery and the competitive market process; an Austrian approach. J Econ Lit 35(1):60-85

Korhonen HME (2014) Widening the perspective on industrial innovation: a service-dominant-logic approach. Technol Innov Manag Rev 4(5):31-39 
Kowalkowski C, Gebauer H, Oliva R (2017) Service growth in product firms: past, present, and future. Ind Mark Manag 60:82-88

Kristensson P, Gustafsson A, Archer T (2004) Harnessing the creative potential among users. J Prod Innov Manag 21(1):4-14

Latour B (2005) Reassembling the social: an introduction to actor-network theory. Oxford University Press, Oxford

Legg S, Hutter M (2007) A collection of definitions of intelligence. In: Advances in artificial general intelligence: concepts, architectures and algorithms, vol. 157, pp 17-24

Lerch C, Gotsch M (2015) Digitalized product-service systems in manufacturing firms. Res Technol Manag 58(5):45-52

Lewin K (1947) Frontiers in group dynamics. In: Cartwright D (ed) Field theory in social science. Social Science Paperbacks, London

Lindgreen A, Hingley MK, Grant DB, Morgan RE (2012) Value in business and industrial marketing: past, present, and future. Ind Mark Manag 41:207-214

Lindhult E, Hazy J (2016) Complexity approach to joint value discovery in service innovation management. Int J Complex Leadersh Manag 3(1/2):115-137

Lindhult E, Hazy J, Midgley G, Chirumalla K (2015) Value driven innovation. A complexity perspective. In: XVI ISPIM conference, Budapest, Hungary, 14-17 June 2015

Lounsbury M, Crumley ET (2007) New practice creation: an institutional perspective on innovation. Org Stud 28(07):993-1012

Lusch RF, Nambisan S (2015) Service innovation: a service-dominant logic perspective. MIS Q 39 (1):155-175

Lusch RF, Vargo SL (2014) Service dominant logic: premises, perspectives, possibilities. CambridgeUniversity Press, Cambridge

Mele C, Colurcio M, Russo-Spena T (2014) Research traditions of innovation: goods-dominant logic, the resource-based approach, and service-dominant logic. Manag Serv Qual 24(6):612-642

Menger C (2007) Principles of economics. Ludwig von Mises Institute, Auburn

Michel S, Brown S, Gallan AS (2008a) Service-logic innovations: how to innovate customers, not products. Calif Manag Rev 50(3):49-65

Michel S et al (2008b) An expanded and strategic view of discontinuous innovations: deploying a servicedominant logic. J Acad Mark Sci 36(1):54-66

Midgley G, Lindhult E (2017) What is systemic innovation? Research Memorandum 101. Hull University Business School, Hull

Miles M, Huberman M, Saldaña J (2013) Qualitative data analysis, 3rd edn. SAGE Publications, Los Angeles

Neely A, Benedetinni O, Visnjic I (2011) The servitization of manufacturing: further evidence. In: 18th European operations management association conference, 3-6 July, Cambridge, UK

Ng ICL, Smith LA (2012) An integrative framework of value. In: Vargo S, Lusch R (eds) Special issue: toward a better understanding of the role of value in markets and marketing, review of marketing research, vol 9. Emerald Group Publishing Limited, Bingley, pp 207-243

Nonaka I, Takeuchi H (1995) The knowledge-creating company: how Japanese companies create the dynamics of innovation. Oxford University Press, New York

Normann R (2001) Reframing business. When the map changes the landscape. Wiley, Chichester

Normann R, Ramirez R (1993) From value chain to value constellation: designing interactive strategy. Harv Bus Rev 71:65-77

O'Cass A, Song M, Yuan L (2013) Anatomy of service innovation: introduction to the special issue. J Bus Res 66:1060-1062

Ordanini A, Parasuraman A (2011) Service innovation viewed through a service-dominant logic lens: a conceptual framework and empirical analysis. J Serv Res 14(1):3-23

Osterwalder A, Pigneur Y (2010) Business model generation: a handbook for visionaries, game changers, and challengers. Wiley, Hoboken

Ostrom AL, Bitner MJ, Brown SW, Burkhard KA, Goul M, Smith-Daniels V, Demirkan H, Rabinovich E (2010) Moving forward and making a difference: research priorities for the science of service. J Serv Res 13(1):4-36

Ostrom A, Parasuraman A, Bowen D, Patricio L, Voss C (2015) Service research priorities in a rapidly changing context. J Serv Res 18(2):127-159 
Parida V, Sjödin DR, Wincent J, Kohtamäki M (2014) Mastering the transition to product-service provision: insights into business models, learning activities, and capabilities. Res Technol Manag 57 (3):44-52

Paswan A, D'Souza D, Zolfagharian M (2009) Toward a contextually anchored service innovation typology. Decis Sci 40(3):513-540

Pierce CS (1955) Philosophical writings of pierce. Dover, New York

Pohlmann A, Kaartemo V (2017) Research trajectories of Service-Dominant Logic: emergent themes of a unifying paradigm in business and management. Ind Mark Manag 63:53-68

Porter ME, Millar VA (1985) How information gives you competitive advantage. Harv Bus Rev 63 (4):149-160

Prahalad CK, Ramaswamy V (2004) Co-creation experiences: the next practice in value creation. J Interact Mark 18(3):5-14

Rayport JF, Sviokla JJ (1995) Exploiting the virtual value chain. Harv Bus Rev 73:75-85

Schön D (1983) The reflective practitioner: how professionals think in action. Avebury, Aldershot

Schön D, Rein M (1994) Frame reflection: toward the resolution of intractable policy controversies. Basic Books, New York

Skålén P, Gummerus J, Koskull CV, Magnusson PR (2014) Exploring value propositions and service innovation: a service-dominant logic study. J Acad Mark Sci 43:137-158

Smith L, Maull R, Ng ICL (2014) Servitization and operations management: a service dominant-logic approach. Int J Oper Prod Manag 34(2):242-269

Sommer AF, Hedegaard C, Dukovska-Popovska I, Steger-Jensen K (2015) Improved product development performance through Agile/Stage-Gate hybrids: the next-generation Stage-Gate process? Res Technol Manag 58(1):34-45

Sosna M, Trevinyo-Rodriguez RN, Velamuri SR (2010) Business model innovation through trial-anderror learning: the Naturhouse case. Long Range Plan 43:383-407

Svensson L, Ellström P-E, Brulin G (2007) Introduction: on interactive research. Int J Action Res 3 (3):233-249

Toivonen M (2016) Service innovation. Novel ways of creating value in actor systems. Springer, Japan

Toivonen M, Tuominen T (2009) Emergence of innovation in services. Serv Ind J 29(7):887-902

Van de Ven AH, Polley DE, Garud R, Venkataramen S (1999) The innovation journey. Oxford University Press, New York

Vandermerwe S, Rada J (1988) Servitization of business: adding value by adding services. Eur Manag J 6 (4):314-324

Vargo S, Lusch R (2004) Evolving to a new dominant logic for marketing. J Mark 68(1):1-17

Vargo SL, Lusch RF (2008) From goods to service(s): divergences and convergences of logics. Ind Mark Manag 37(3):254-259

Vargo SL, Lusch RF (2011) It's all B2B... and beyond: toward a systems perspective of the market. Ind Mark Manag 40(2):181-187

Vargo S, Lusch R (2012) The nature and understanding of value: a service-dominant logic perspective. In: Vargo S, Lusch R (eds) Special issue-toward a better understanding of the role of value in markets and marketing, review of marketing research, vol 9. Emerald Group Publishing Limited, Bingley, pp 1-12

Vargo S, Wieland H, Akaka MA (2015) Innovation through institutionalization: a service ecosystems perspective. Ind Mark Manag 44:63-72

von Mises L (1949, 1998) Human action. A treatise on economics. The Scholar's Edition. Ludwig von Mises Institute, Auburn, Alabama

Witell L, Snyder H, Gustafsson A, Fombelle P, Kristensson P (2016) Defining service innovation: a review and synthesis. J Bus Res 69:2863-2872

Yin RK (2009) Case study research: design and methods. Sage Publications, Thousand Oaks 